\title{
A Research on China's Infrastructure Investments in ASEAN in the Context of The Belt and Road
}

\author{
Yue Nian \\ International Business School \\ Yunnan University of Finance and Economics \\ Kunming, China \\ 2312363393@qq.com \\ Duan Yunlong* \\ International Business School
}

\author{
Yunnan University of Finance and Economics \\ Kunming, China \\ 827987867@qq.com
}

\author{
Yang Lisheng \\ School of Management \\ Yunnan Minzu University \\ Kunming, China \\ 398508316@qq.com
}

\begin{abstract}
ASEAN is the fast growing economic entity, so the market contains huge investments and demands. In terms of infrastructure, most of the ASEAN countries are lagging behind in electricity, transportation and communication. Well,the governments have imposed a large number of preferential policies, which provides huge opportunities for China to increase its investments in ASEAN infrastructure.

Meantime, the goal of the "The Belt and Road" or "New Silk Road" program is to expand the infrastructure between continents and strengthen the co-operations in politics, economy and so on. So this paper mainly discusses the infrastructure status and needs in ASEAN, analysis the reasons, status and problems of infrastructure investments from China and the corresponding countermeasures.
\end{abstract}

Keywords—infrastructure; investment; ASEAN

\section{INTRODUCTION}

In the The Belt and Road, ASEAN is an important economic entity that closes to China. The friendly economic development of ASEAN and China is vital. Guo Hongyu and Zhu Caihua (2014) [1] pointed out that we should strengthen the strategic mutual trust between China and ASEAN, pay attention to the docking of China and ASEAN industry.Zhong Shuyan (2015) [2] believed to improve the assessment and regulatory mechanisms, make full use of new financing channels and differentiate investments to avoid investment risks and other countermeasures and suggestions.

In my views,infrastructure interconnection as a priority area for the construction of The Belt and Road in the 21st century, it is the strong power that promotes trade obviously and will enter into a new period of rapid development, bring new opportunities for China's investments in infrastructure construction in ASEAN .

\section{THE INFRASTRUCTURE STATUS IN ASEAN}

Infrastructure refers to the material engineering facilities that provide public services for social production and residential life. It is including roads, railways, airports, communications, post and telecommunications, water supply and so on.With regard to the functions of infrastructure in short, it is based on the research results of Guo Hong, Ge Shunqi (2016) [3]: As a public service system, the infrastructure

played an important role in promoting trade investment, economic growth and improving poverty.

According to the World Bank, GDP is also growing by $1 \%$ for every $1 \%$ increase in infrastructure. ASEAN countries have experienced decades of economic growth, but at present, the level of infrastructure construction is close to the world average, still lagging behind the average level, especially in Myanmar, Laos, Cambodia and the Philippines.

As a whole(The results are shown in Table1),the overall level of infrastructure in ASEAN is close to the world average, while the top three are Singapore (6.50), Malaysia (5.42) and Thailand(4.39), while Cambodia, Laos and Myanmar are the latter three.

TABLE I. ASEAN COUNTRIES' INFRASTUCTURE EVALUATION INDEX

\begin{tabular}{|l|l|l|l|l|l|l|}
\hline Index & Overall level & Highway & Railway & Port & Aviation & Electricity \\
\hline World average & 4.1 & 4.1 & 3.4 & 4.0 & 4.4 & 4.6 \\
\hline ASEAN & 4.0 & 4.0 & 2.7 & 3.9 & 4.4 & 4.6 \\
\hline Singapore & 6.50 & 6.3 & 5.7 & 6.7 & 6.9 & 6.8 \\
\hline Malaysia & 5.42 & 5.5 & 5.1 & 5.4 & 5.7 & 5.8 \\
\hline Thailand & 4.39 & 4.2 & 2.5 & 4.2 & 5.0 & 5.1 \\
\hline Indonesia & 4.24 & 3.9 & 3.8 & 3.9 & 4.5 & 4.2 \\
\hline Philippines & 3.37 & 3.1 & 2.0 & 2.9 & 3.2 & 4.0 \\
\hline Vietnam & 3.88 & 3.5 & 3.1 & 3.8 & 4.1 & 4.4 \\
\hline Laos & 3.08 & 3.4 & - & 2.0 & 3.8 & 4.7 \\
\hline Cambodia & 3.17 & 3.4 & 3.4 & 3.9 & 3.9 & 3.3 \\
\hline Brunei & 3.88 & 4.7 & - & 3.7 & 4.1 & 5.3 \\
\hline Myanmar & 2.1 & 2.3 & 1.8 & 2.6 & 2.6 & 2.7 \\
\hline
\end{tabular}

Data Sources : World Economic Forum, The Global Competitiveness Report 2016-2017

* Corresponding author 
Specifically, for the highway, Singapore, Malaysia and Brunei's facilities are better, the indicators are 6.3,5.5,4.7 respectively ; The indicators of Philippines, Laos, Cambodia and Myanmar are very low, indicating that the road laying density of these countries is very low.Most of the countries are mud and sand roads. As the road condition is poor, it seriously affects the transport of goods.

From the point of the railway, the average index of the ASEAN countries' transportation industry is slightly lower than the world average, but Singapore, Malaysia and Indonesia are higher than the world average of 3.4, indicating the railway construction gap between countries in ASEAN. In fact, in 2007, Laos just opened the first railway. Cambodia only had two railways which near to paralyze. If the Pan Asian Railway can be successfully completed, it will have a big deal for bilateral trades.

For the port, Laos and Myanmar are 2.0 and 2.6 respectively, far below the world average of 4.0. In addition to the level of economic development between the two countries, they are landlocked countries that do not have geographical advantages to build the ports.

For air transport, it is better in Singapore, Malaysia and Thailand. However,due to the high cost of air transport and most of the ASEAN countries' aviation infrastructure is not perfect, so the main business is goods transportation .

From the view of the power, Cambodia and Myanmar have the low power index, also lower than the world level. The gap of the electricity indicators seriously affects the per capital power consumption and power rate in ASEAN.

\section{THE INFRASTRUCTURE INVESTMENT NEEDS IN ASEAN}

Owing to the monetary in the United States,ASEAN countries have carried out the plans of economic reconstruction, causing certain impacts on the ASEAN's real economies, gradually turned to stimulate domestic demands, increased domestic infrastructure investment to promote domestic economic growth and improve the local investment environment.

According to Shao Tong (2014) [4], in recent years, ASEAN countries have launched a huge investments in infrastructure projects, involving land, sea and air transport, power communication, financial security, agriculture, tourism, scientific and technological information and human resources and other infrastructure constructions.

According to the World Economic Forum, ASEAN countries are expected to invest an average of $\$ 1.1$ trillion in infrastructure in the region in 2010-2020. At present, ASEAN countries have developed national infrastructure development plans. For example,Brunei is preparing a comprehensive plan for land transport; the Indonesian government formally promulgates the plan about accelerating and expanding economic development from 2011 to 2025, develops the "six economic corridors" development strategy. In 2015, Malaysia began to implement the 11th Malaysia program, which announced the need to promote the growth of the implementation of important infrastructure projects. After the completion of 10 power plants, Myanmar plans to build 87 power plants.

Large infrastructure plans require huge capital investment. ASEAN countries, the main source of infrastructure construction is the domestic public finance, but the local economic development level is limited, so the urgent need is a large number of private investments and overseas capital. Take Indonesia for example,in 2014 , the government set the infrastructure construction as its political commitment that paid much attention by the Indonesian people. It was also an important goal for Indonesia's national development. The Indonesian government hoped that the relevant work would be initiated to provide financial support for long-term projects so as to enhance the national competitiveness and promote economic prosperity and development.

For ASEAN countries, finding capital that can be used and directed into appropriate infrastructure projects is a key step in infrastructure development. Some local governments provide preferential policies such as tax-free or government guarantees for infrastructure in public-private partnerships.

In general, the ASEAN countries have a positive attitude towards the infrastructure investment for overseas capital.

\section{THE INFRASTRUCTURE INVESTMENT REASONS AND STATUS FROM CHINA}

\section{A. The infrastructure investment reasons}

The key step in The Belt and Road is to strengthen the infrastructure between China and neighboring countries. Therefore, the reasons for China's investment in ASEAN infrastructure are analyzed from two perspectives.

\section{1) Domestic reasons}

To develop the new market for China's high capacity: Overcapacity threatens the development of China's economy and investments in ASEAN infrastructure markets can alleviate the excess capacity. Firstly, infrastructure construction requires a lot of steel, cement and other building materials, which to some extent for China's excess capacity can create a great market demand; Secondly, improve the infrastructure level can expand the export channels and modes of transport for China's products, contribute to the output of the product. At the same time, infrastructure construction can promote the development of the local economy, increasing the potential purchasing power for our products.

To facilitate the energy introduction for China:With the sustained and rapid development of China's economy, the demand for energy will continue to rise. ASEAN countries are also relatively rich areas of energy, especially natural gas reserves. Indonesia. Malaysia, Brunei are the traditional oil and gas producing and exporting countries; Vietnam and Cambodia are the emerging oil and gas producers; The oil processing and shipping in Singapore are well known. The good infrastructure conditions of ASEAN not only can promote energy trade and transport between the two regions, but also can be an important transport guarantee for China's energy introduction. 
To find a way out for China's foreign exchange reserve: The too high foreign exchange reserve has become a heavy burden for China's economic development. Infrastructure construction itself has the characteristics of large demands for funds, coupled with the scarce infrastructure funds in ASEAN, if the foreign exchange reserve is invested in ASEAN countries, it will be very useful in promoting regional cooperation, promoting the integration, achieving the preservation and appreciation of China's foreign exchange reserve.

\section{2) Regional reasons}

China and ASEAN have built the world's largest free trade zone among developing countries, the exchanges and goods of both sides have become increasingly close. However, the supply of infrastructure in the area is not enough. Many countries in ASEAN, especially Cambodia, Vietnam and other countries are short of funds in infrastructure. Building a high level of infrastructure will directly affect the cooperation between China and ASEAN. It not only benefits the economic developments between China and ASEAN countries, but also can promote the two sides to facilitate investments.

\section{B. The infrastructure investments'status}

China and ASEAN have experienced economic and trade cooperation during the "Golden Decade" period, due to the ASEAN countries, the market demands for infrastructure construction are strong, the investments from China in infrastructure construction have been rapid and stable and have completed the Jililong 3 hydro-power station, that pile- Ba yon Road, the sun-clear hole bridge and other large infrastructure projects.

In 2017, according to the statistics from the Ministry of Commerce of the People's Republic of China, the nonfinancial direct investment is mainly in Singapore, Laos, Indonesia, Cambodia, Malaysia and so on.

Infrastructure investments mainly involve transportation, electricity, communication and other fields. The main investment objects are in Indonesia, Vietnam, Singapore, Malaysia, Myanmar and the Philippines.

As China's infrastructure investments in ASEAN gradually increasing, some real problems have become increasingly prominent, which has become a major obstacle to the further development of bilateral co-operations.

\section{The EXISTING INFrastruCture INVESTMENT PROBLEMS IN ASEAN}

\section{A. Political mutual trust needs to be deepened}

Guo Hongyu and Zhu Caihua (2014) [5]said ChinaASEAN infrastructure interconnection had also encountered many obstacles, these resistances were mainly from the political factors.

In recent years, the comprehensive strategic partnership of China-ASEAN has been consolidating and developing .Mutual political trust has been increasing. The co-operations of economic and trade have been continuously expanded. However, with the peaceful rise of China, the world economic and political center has accelerated the transfer to the Asian-
Pacific region. Some Western countries even have publicized the "China threat," triggering concerns of the ASEAN countries. At the same time, due to the existence of the sovereignty disputes between China and some ASEAN countries, the involvement of various foreign power has led to the warming of the South China Sea dispute, which has a greater negative impact on the development of China-ASEAN political mutual trust and becomes the biggest barrier for China-ASEAN politics, also directly affects the further developments of bilateral economic and trade co-operations.As a result, China's investments in infrastructure projects in ASEAN countries are mainly confined to highway, railway, inland hydro-power project. It is difficult to achieve a breakthrough in the harbor, nuclear power plants, electronic equipment and other major projects.

\section{B. Lack of financing channels and financial services support}

First, ASEAN countries are affected by the colonial rules, as a result, the economic foundation is weak. From 2010 to 2020, infrastructure investment demand is expected to about 1.1 trillion dollars, while the current major financing channels are the World Bank and the Asian Development Bank. The registered capital of them is respectively 223 billion dollars and 160 billion dollars. They can only offer the loans of about 20 billion dollars each year for the ASEAN, so there is a huge funding gap restricting the ASEAN to promote the construction of infrastructure.

Second, the main platform for cooperation between China and ASEAN countries, such as the APEC Finance Ministers' Mechanism, the ASEM Finance Ministers' Mechanism and the "10 + 3" Finance Ministers' Mechanism mainly play the role of assessment and communication, but they are lack of effective supervision, crisis warning and other functions, resulting in the increasing systemic risk greatly for Chinese enterprises to invest in infrastructure.

Third,for parts of the Asian countries, financial institutions can not provide Chinese-funded enterprises to improve the financing services, coupled with the Chinese-funded commercial banks that do not enter the local business. So enterprises are facing financing difficulties. This may make some private enterprises finance through the underground bank financing, facing a lot of risks and dangers.

\section{Poor investment environment}

Enterprises investing in Southeast Asian countries are not only influenced by the policies, but also encounter lazy, corruption and other issues. Yunnan International Economic and Technical Cooperation Manager Yang Ting says that some Southeast Asian countries' procedures are not formal, some of the tax items are temporary and some government staffs will not work if they can not get money.

\section{Poor industry supporting}

The infrastructure is not complete,which becomes an important factor restricting business investments in Southeast Asia.In Indonesia, investments in agricultural plantations need to spend a lot of money to help the local power and water. 


\section{E. The security mechanism is not perfect.}

Some ASEAN countries have complicated political and economic environments, Chinese enterprises lack the market experience, local financing, management and the ability to risk.

From the inside of ASEAN, its internal cohesion is not strong, fails to establish effective coordination mechanism to solve the internal interests of differences. The region's infrastructure investment projects in the overall rational layout, unified construction standard, income compensation mechanism and environmental protection mechanism are not complement.

\section{F. Culture and custom are diverse}

In the ASEAN countries, Buddhism, Islam and the original religious coexistence, the formation of distinctive regional culture. Moreover, countries will have different cultural characteristics. In the ASEAN countries, the attitudes towards China are not the same.ASEAN countries' cultural customs would affect the investment strategies of Chinese investors and the things to handle.

\section{THE INFRASTRUCTURE INVESTMENT RECOMMENDATIONS IN ASEAN FOR CHINA}

In the 21st Century, China's investments in infrastructure in ASEAN must firmly grasp the opportunities and facilities provided by the strategy of The Belt and Road, break through the obstacles and bottlenecks for China's investments in ASEAN, further develop the infrastructure investments. So we must do as follows:

\section{A. Engage in political dialogue and promote peaceful development}

Continue to maintain high-level visits and constantly strengthen China and ASEAN in the political field of cooperation to further multilateral and bilateral political security dialogue and consultation. For the territorial sovereignty of the issue, consult in good faith to maintain peace and stability .

\section{B. Make full use of new financing channels}

Continue to increase co-financing arrangements, said by Xia Luojia (2016) [6]. The Chinese state leaders expressed their willingness to set up special funds to provide financial support for infrastructure construction. Chinese National President Xi Jin ping proposed a \$ 100 billion investment from China to establish an Asian Infrastructure Investment Bank and take the PPP (public-private partnership) model. It is not only for the ASEAN countries to obtain new financing channels in the World Bank and the Asian Development Bank system, but also provides timely and effective financing support for China's investment in ASEAN countries. During the Beijing APEC meeting in 2014, China also announced the investment of 40 billion dollars to set up Silk Road Fund,which was based on Shen Fengxian, Wu Qi and Wang $\mathrm{Ke}$ (2016) [7]. In addition, the "bank + fund" model would effectively solve the financing problem in the process of infrastructure investments for our enterprises to increase investments in infrastructure projects in ASEAN.

\section{Strengthen communication and management to promote investment}

Strengthen communication and cooperation with the relevant consulting and development departments of the ASEAN countries, understand the policies and business terms of the local government. Choose the good development companies with good reputations, reduce investment resistances and blind spots. Make full use of the local governments' investment preferential policies to absorb the reliable financing, infrastructure and its supporting industries to build cooperation.

\section{Improve the infrastructure investment protection mechanism}

Wang Qi (2015) [8] said, the demand for investment money is much large and the construction period is long. Therefore, it is necessary to clarify the dispute settlement method and legal basis, which can not only protect the rights and interests of Chinese enterprises, but also can guarantee the construction of overseas infrastructure projects.

Chinese enterprises in the ASEAN investment infrastructure should use new ideas and the international advanced dispute settlements in the contract. While building a multilevel dispute solution. It is necessary to clarify the pros and cons of the various dispute settlements and the conditions of application. The contract should indicate the applicable law.

On the basis of understanding the law, we should also understand the relevant policies of the host governments. Actively build a multilevel inter government macro-policy communication and exchange mechanism, fully exchange and formulate economic development strategies and countermeasures. Establish specialized agencies, coordinate national policies, develop infrastructure cooperation planning, unify technical standards, strengthen the infrastructure project construction supervision and evaluation to ensure that the regional infrastructure construction layout is reasonable and systematically.

\section{E. Accelerate the investment in supporting infrastructure}

The cooperation projects should be including the traditional roads, railways, inland bridges, waterways, landbased communications network construction, the harbor terminals, sea waterways, nuclear power plants, nuclear power plants, maritime communications and other projects. The investments in these projects are not only conducive to find a new investment in infrastructure, but also help to promote China and ASEAN countries in the sea pragmatic cooperation.

\section{F. Deepen cultural understanding and communication}

Chinese enterprises can hire local business professionals as the company's investment and development consultants and strive to understand the cultural differences between countries, adjust to the local community environments, avoid violations of local customs and habits; Develop the policies in line with local development investment programs and economic decision. ASEAN is one of the key surrounding areas for China. In recent years, China and ASEAN countries have repeated that 


\section{CONCLUSIONS}

Inter-modulation is a priority area and the key point for bilateral cooperation. In the construction of regional interconnection network, interconnection of infrastructure is the most important.

The Belt and Road is in line with the national interests and development plans of most ASEAN countries. It will inject new vitality into China-ASEAN cooperation. Infrastructure as a priority area for construction, countries should give high priority to promote the economies to a new stage of development.

\section{ACKNOWLEDGMENT}

At the time of completion of this paper, Firstly, thanks to my tutor, Duan Yunlong, for his help in the design,implementation and writing process. This topic is under the tutor's careful and earnest care to complete, heartfelt thanks to the teacher. Secondly, I would like to thank my classmates those who have supported me in silence, please accept my sincere thanks.In the end, I would like to express my sincere gratitude to all the people who care about me, love me and give me help.

\section{REFERENCE}

[1] H.Y. Guo, and C.H. Zhu, "Problems and Countermeasures of ChinaASEAN Infrastructure Interconnection Construction," International Economic Cooperation, voi. 8, 2014, pp. 26-31.

[2] S.Y. Zhong, "21st century sea silk road" under the background of China's ASEAN infrastructure investment research," Southeast Asia, 2015, pp. 10-15.

[3] H. Guo, and S.Q. Ge, "China's investment in ASEAN infrastructure research," International Economic Cooperation, vol. 12, 2016, pp. 4853.

[4] T. Shao, "ASEAN countries, infrastructure and economic development research," Xiamen University, 2014

[5] H.Y. Guo, and C.H. Zhu, "Problems and Countermeasures of ChinaASEAN Infrastructure Interconnection Construction," International Economic Cooperation, vol. 08, 2014, pp. 26-31.

[6] L.J. Xia, "Grasp the new opportunities for cooperation, build a new route of the sea-2016 China - ASEAN Infrastructure Cooperation Forum was successfully held," International Engineering and Services, vol. 10, 2016, pp. 37-39.

[7] F.X. Shen, Q. Wu, and K. Wang, "The impact of China's leading Asian infrastructure investment banks on ASEAN member countries,' Nanyang Information Translation, vol. 03, 2016, pp. 13-18.

[8] Q. Wang, "A road strategy under the background of Chinese enterprises in ASEAN infrastructure investment legal issues," Guangxi Normal University, 2015. 